This paper focuses on the subtitling of film festivals and particularly on the specificities of electronic subtitles manually launched via projector. The process carried out from the commissioning of the subtitling of a film festival to the launching of electronic subtitles during screenings will be explained based mainly on the professional experience of the author at a small Spanish subtitling company. The article aims to give more visibility to this Audiovisual Translation modality in order to highlight its peculiarities. Besides, in the context of the Spanish crisis, where working conditions are being worsened in every sector and the budget for culture has been cut by half in the last four years, it is crucial to underline the relevance of good quality subtitling as well as the positive influence of film festivals on society.

KEY WORDS Audiovisual Translation (AVT), Electronic Subtitling, Film Festivals, Subtitling.

\title{
Subtitling for Film Festivals: process, techniques and challenges
}

\section{La subtitulación de los festivales de cine: proceso, técnicas y reto}

Este artículo describe la subtitulación de los festivales de cine, en concreto, las especificidades que presentan los subtitulos electrónicos lanzados de forma manual por medio de un proyector. Basándose fundamentalmente en la experiencia profesional de la autora en una empresa de subtitulación española, se explicará el proceso que se lleva a cabo desde que se encarga la subtitulación de un festival hasta que se lanzan los subtítulos electrónicos en sala. El presente artículo tiene como objetivo dar mayor visibilidad a esta modalidad de traducción audiovisual

Anjana Martinez-Tejerina con el fin de subrayar sus peculiaridades. Asimismo, en el actual contexto de crisis, donde las condiciones laborales continúan empeorando en todos los sectores y el presupuesto destinado a cultura se ha recortado a la mitad en los últimos cuatro años en España, es crucial subrayar la importancia de una subtitulación de calidad, así como la influencia positiva que tienen los festivales de cine en la sociedad.

PALABRAS CLAVE Traducción audiovisual (TAV), subtitulación electrónica, festivales de cine, subtitulación 


\section{INTRODUCTION}

Since the birth of film festivals their number and diversity have greatly increased. This 216 kind of events seeks different artistic, cultural, lucrative or political goals. This paper is going to focus on festivals which show films that rarely appear in mainstream media. Three of the most important contributions of this kind of festival to society are that they give voice to minorities, that they enhance an understanding between different communities, and that they offer novel filmmakers an opportunity to screen their movies. According to Czach (2010: I4I), "[f]ilm festivals present a seductive return to classical cinephilia with their promise of a unique, unrepeatable experience frequently offering a rare opportunity to view films on the big screen before they disappear into the ether or only reappear on DVD".

Film festivals allow products from different countries to travel throughout the world. In the case of international film festivals, copies need to be an original version with subtitles in the language of the host country, and films selected for international competition are often required to include English subtitles as well. Hence, a lot of languages are involved in the process and many translations are needed.

Different Audiovisual Translation (AVT) modalities have been used in film festivals: electronic subtitling, live voice-over or simultaneous interpreting, to name but a few. While countries such as Germany, Italy or Poland often use live interpreting (Lecuona 1994, Russo 1997, 2000, 2003, 2005, Jüngst 20II), in Spain the most widely used modality is electronic subtitling. In fact, since the introduction of electronic subtitling, the rest of modalities is rarely used (Bartoll, 2008: 103).

The electronic subtitling technique may vary depending on launching methods, diffu-

sion methods (Bartoll, 20I2b: IO2) and software systems. Firstly, subtitles may be launched automatically or manually. While some companies use a system which automatically projects the subtitles, others rely on technicians who manually launch each subtitle in the cinema while the film is being screened ${ }^{\mathrm{I}}$. In this paper the term subtitle launchers will be used to refer to these technicians.

Secondly, subtitles may be emitted by a LED display or projected by a projector (Bartoll, 2008: 202). There are other diffusion methods such as special glasses equipped with mini screens -a prototype created at Universidad Carlos III from Madrid- or mobile applications: the Universal Accessibility System (UAS), created to deliver subtitles for the dead and hard of hearing as well as audiodescriptions for live performances (Bartoll, 20I2b: 88-89) ${ }^{2}$, or MovieReading, which allows viewers to display subtitles on their smartphones or tablets in synchronization with the film being screened.

Thirdly, most companies develop their own specific software to launch subtitles, but sometimes mainly in opera and theatre, PowerPoint ${ }^{3}$ is used (Bartoll 2or2b, Di Giovanni 2007).

Drawing on my professional experience at a small Spanish subtitling company specialized in film festivals, this paper focuses on the specifi-

I This system is especially useful in the opera and in the theatre since rhythm is continuously changed in those performances (Bartoll, 20I2a: 33).

2 This system has been developed by Centre d'Accesibilitat i Intel-ligència Ambiental de Catalunya (CAiAC) from Universitat Autònoma de Barcelona in collaboration with three theatres from Barcelona: Gran Teatre del Liceu, Teatre Nacional de Catalunya and Teatre Lliure. "While the system is not commercially available, it is fully operational at the cinema at Universitat Autònoma de Barcelona (Spain) where during the academic year 20II/I2 five films were programmed"(Oncins et al, 20I2: 159).

3 Oncins $(2013 \mathrm{~b})$ mentions the main commercial surtitling software available aside from PowerPoint: Figaro, Vicom, Naotek, Supertitles and Opera Voice. 
cities of electronic subtitles manually launched via projector. The process carried out from the commissioning of the project to the launching of electronic subtitles during screenings as well as working conditions and challenges will be explained from the point of view of translators and subtitle launchers.

\section{ELECTRONIC SUBTITLES}

\section{The origin of electronic subtitling}

Electronic subtitling was created by Fabrizio Fiumi, a Florentine architect and inventor, in I984 (Bartoll, 2or2b: 86). According to a newspaper of the time (Miami News, I986) Fiumi wanted to improve the subtitling technique for three reasons: subtitles took up ten percent of the image that the director may have taken days to compose, their visibility may be jeopardized for reasons of space and background, and they could not be changed or removed because the dialogue was corroded into the print with acid. According to Bartoll (2012b: 86), another reason for the creation of this new system was the need to lower the costs of subtitling.

Fiumi invented a new system in which the celluloid was untouched by acid and subtitles appeared above or below the screen. The method consisted in the projection of subtitles from a separate file while the film was being screened. Therefore, the film and the subtitles were projected simultaneously and independently. A similar method had already been used during the silent film era:

In 1909 M. N. Topp registered a patent for a 'device for the rapid showing of titles for moving pictures other than those on the film strip'. With this method the projectionist, using a sciopticon (a kind of slide projector), showed the subtitles on the screen below the intertitles. (Ivarsson, 2004).
In Fiumi's view, the most important feature of electronic subtitling for the audience is that "this makes the subtitles an option, which can be looked at when necessary, rather than an imposition which can't be avoided" (Raynor ,I986: 30).

\section{Advantages and disadvantages of electronic subtitling}

There are four reasons why electronic subtitling is the most widely used AVT modality for film festivals in Spain. Firstly, the process is fast. While burnt in subtitles require a phase of spotting, manually-launched electronic subtitles only entail a rehearsal or pre-view: subtitle launchers receive the translation (already segmented in subtitles but without timecodes) and watch the film while simulating the launching of subtitles on their computers. This task requires less time than spotting and time is a crucial factor in film festivals because movies usually arrive in the country where they are going to be shown only days (or even hours) before the screening.

Secondly, electronic subtitling is an inexpensive AVT modality. Companies charge lower fees for this kind of subtitling because it minimizes the time invested in synchronization and because subtitle launchers do not need as much training or experience as other professionals in the sector such as subtitlers (who create the spotting of the subtitles) or interpreters.

The economic factor is always crucial in cinema (which after all is an industry) and it is even more important in film festivals, where budgets are usually tight. Films may be screened only once or twice to a minority audience, which makes a considerable investment of money unprofitable.

In the case of big productions screened in international film festivals hosted in dubbing 
countries, subtitling represents an additional cost for the film industry "where subtitles remain an intermediate step before the release 218 in other distribution platforms mainly: theatres, DVD or Blu-ray or Video-on-demand" (Oncins, 20I3a: 74).

Thirdly, the copy of the film is not "spoiled" by this kind of subtitling. Subtitles and films are independent files that are projected simultaneously. Therefore subtitles are not burnt in on the film. This is crucial in film festivals. Copies in traditional film formats ( $16 \mathrm{~mm}$ and $35 \mathrm{~mm}$ ) are very expensive and since sending different copies to each film festival would require a considerable amount of money, the same copy travels throughout the countries where the film is screened. With electronic subtitling this copy remains intact. Nevertheless this drawback of burnt in subtitling is not so problematic these days because many films are shot now in digital formats and, since copies are more economical, filmmakers can afford to send a different copy to each country.

Fourthly, subtitles are projected independently and most of the time on an isolated screen. Therefore they are compatible with any kind of format: $35 \mathrm{~mm}, \mathrm{I} 6 \mathrm{~mm}$, DVD, Blu-ray, and so on. Hence, as we have mentioned before, electronic subtitling is not only used at film festivals, but also at live performances such as theatre plays and operas.

Nevertheless, electronic subtitling also has disadvantages. The main drawback of manually launched electronic subtitles is that it does not achieve the precision of burnt in subtitles, which appearance on screen is carefully calculated frame by frame. It would be hugely interesting to carry out reception research and analyze if the difference between electronic and burnt in subtitling is perceived by spectators.

\section{THE PROCESS: FROM THE COMMISSIONING TO THE SCREENING}

\section{The commissioning}

Once the subcontracted company receives a commission to subtitle a film festival, project managers need to find the most suitable (and available) translators, revisers and subtitle launchers ${ }^{4}$ for each film taking into account that the commission may change. For instance, extra films may be added at the last minute, which will force all the professionals involved in the process to work overtime and on tight deadlines. Other films may also be cancelled due to changes on the festival's programme or due to the characteristics of the final screening copy. For example, the film festival may find out in the middle of the translation process that the copy that is going to be projected already has burnt in subtitles in the target language.

At this stage it is very important to make sure that the video the subtitling company has received is a copy of the film that will be projected at the festival - the screening copy. Sometimes it is impossible to receive this copy because the final cut of the film may not be ready until the last minute, which means filmmakers may make changes right until the screening.

\section{The translation}

Translators receive an email from the project manager asking for their availability to translate a film (or several films). The address of a server where the video has been uploaded as well as a written source text are normally provided.

4 It must be clarified here that even though this modality requires more professionals than conventional subtitling its cost is lower because the fees for translation, revision and subtitle launching are lower than for translation, revision and spotting. 
The translators' task consists in rendering a translation segmented in subtitles that follow some of the space and time restrictions applied to burnt in subtitles, such as a maximum of 2 lines per subtitle and of 37 characters per line. Nevertheless manually launched electronic subtitles differ from burnt in subtitles in two main characteristics. Firstly, no timecodes are needed since subtitles will be manually launched during the screenings. Secondly, shot changes are not taken into account for the segmentation because subtitles are normally projected on an independent screen and because of the lack of precision commented above.

\section{The video}

The videos translators work with normally have watermarks and poor quality for two reasons: to avoid piracy and because of the limited storage capacity of the servers.

It is quite frequent to receive videos with burnt in subtitles and on most occasions these subtitles are in English. In that case, the translator should ask if the screening copy includes them as well. If that is the case, the translator should bear in mind the two main consequences of the appearance of more than one subtitle track. Firstly, the segmentation of the target text may be conditioned by the burnt in subtitles. It is common and advisable that in order not to distract the viewer with constant flashes created by the two subtitle tracks appearing at different rates, translators decide to segment their electronic subtitles exactly as the burnt in subtitles (or in a very similar way), that is to say, electronic subtitles tend to imitate the segmentation of burnt in subtitles. In spite of this similarity, Oncins (2013a: 78) warns that subtitle tracks will "present different lengths due to the language differences and also exposition time might be slightly larger for the projected subti- tles to allow readability times". It is also relevant to mention here that this practice is not advisable when the burnt in subtitles quality is poor and subtitling conventions or reading speed limits are not respected.

Secondly, this double subtitling leads to a double vulnerability: the viewer has access to the subtitles in his/her language as well as to a written text (much easier to understand than an oral text) and therefore can easily compare the two versions. Di Giovanni (2007: 60) illustrates this situation with the experience of one student: "she decided not to move the direct reference to Samson in the previous block, since the viewers would have found no corresponding reference in the English subtitle printed on the film". When the original version is shot in a language similar to the one spoken in the target country -such as Portuguese or Italian in Spanish film festivals - the vulnerability of the translation rendered by electronic subtitles is even bigger since the audience may not only understand the burnt in subtitles but also the audio.

\section{The written source text}

Regarding written source texts we should mention that they are extremely varied: preproduction scripts, spotting dialogue lists, standard lists, master subtitles or a combination of these types. Therefore the information provided by written source texts range from incomplete or inaccurate versions of the dialogue exchanges in the film to faithful transcriptions accompanied by context (action, screen text and camera movements), subtitles in the original language and additional linguistic and extralinguistic information -definition of idioms and colloquialisms or explanation of cultural elements and puns.

Unfortunately written source texts are not always reliable and in fact they usually con- 
tain errors and omissions. It is important to highlight that they are just a helpful tool for translators to fully understand the dialogue, but 220 it is the film, the multi-code text, that has to be translated. In spite of this intrinsic feature of AVT, some translators are only provided with the written source text. This practice is counterproductive and may only lead to poor quality subtitles because the audiovisual text is a conglomerate of codes where the image is as important as the audio; therefore it is not possible to coherently translate the film by only having access to one of its codes (Chaume 2004).

When a film is not accompanied by a written source text, some companies pay a native speaker to transcribe the dialogue. In order to create a quality transcription, transcribers need to document themselves, especially in the case of proper nouns and cultural references they may not be familiar with. When transcribers leave a gap or a question mark in the text, they are passing on an unsolved problem to the translator.

When the festival organizers do not supply a written source text and there is no time to transcribe the audio, translators may have to rely only on the film, which may be quite difficult if the sound is not good, if the characters have strong accents or if the background noise is loud.

The subtitling of films shot in lesser-known languages such as Tagalog or Wolof has its own peculiarities. When this kind of films arrives in Europe they are very often accompanied by written source texts in which only the English subtitles are provided. Therefore the translation to other languages is based on a compressed English translation instead of on the audio, which means that it is actually the translation of a translated text, not the translation of the original version. "[T]he genesis file is invariably an English-language dialogue list, no matter the source language of the film itself. [...] As this globalized business strategy goes mainstream, media translators find the genesis file increasingly difficult to evade" (Nornes, 2007: 235).

The genesis file or pivot translation (Gottlieb, I997: I27-I28) is indeed a widespread practice (Díaz-Cintas \& Remael, 2007: 32, 250) that not only has to do with the insufficient knowledge of the source language and culture of translators in the target culture, but also with other factors such as the working process, the problem of the source text of an audiovisual document, and, last but not least of course with commercial imperatives, that is money and time pressures. Production and distribution companies much prefer to work with English master titles or even intralingual pivots because it allows them to reduce the costs, as it is much cheaper and quicker to have the job done by an adaptor than by a translator (Vermeulen, 20II: I2I).

This practice obviously has an impact on quality. Not translating from the original text (especially with languages and cultures as diverse as Asian or African and Western) may lead to a distortion of what is really being said or intended in the original film.

It also needs to be taken into account that the translation into English is often unreliable, incomplete and full of inaccuracies and grammatical mistakes:

pivot titles in English [...] are frequently printed on the films in the country of origin and they can prove to be difficult to understand, in terms of language use as well as subtitling conventions. Therefore, subtitlers are required to make extra efforts to interpret the pivot titles - the uncommon, often ambiguous references which they may contain - and are compelled to carry out extensive research so as to interpret their 'awkward' source text and produce a smooth-running, clear subtitled version (Di Giovanni, 2007: 57). 
Vermeulen (20II: I23) reaches a similar conclusion after analyzing the Spanish subtitling of the Belgian film De zaak Alzheimer. When dealing with additions introduced during the shooting of the film that were not included in the English translation of the annotated preproduction script that was provided as a written source text, "the translator resolved the problem by rendering a plot-oriented translation that respects the semiotic cohesion, rather than a faithful one".

In conclusion, written source texts have an impact in the quality of subtitles. As Díaz-Cintas (200I: 207) ${ }^{5}$ stated, "A detailed dialogue list is imperative if we are to create a high quality target product, and it is the director's duty, $[\ldots]$ to guarantee that the subtitler receives one of these lists as well as to control the end-product quality".

\section{The revision}

One of the rules proposed by Carroll and Ivarsson (1998) in their Code of Good Subtitling Practice states that each production should be edited by a reviser. Depending on the company in charge of the project, this phase will be implemented or skipped. Revisers need to guarantee the quality of the translation (accuracy, characterisation, register, effect, etc.) as well as the adequacy of the subtitles (segmentation and reading speed, among other features). Required modifications may be implemented by the reviser or the translator, depending on time limitations and the complexity of the changes.

5 In his article "Striving for quality in Subtitling: the role of a good dialogue list”, Díaz-Cintas (200I) describes the different types of dialogue lists translators may receive, as well as their impact on subtitles.

\section{Launching subtitles at film festivals}

Before going to the screening, subtitle launchers -who are often translators as wellwatch the film several times on their laptop while simulating the manual launching of subtitles. During this rehearsal subtitle launchers will identify the more problematic scenes (for instance sequences in which many characters speak at the same time) and practice them as many times as needed.

At the venue, technicians test the film and make sure that sound and image match the requirements of the director, who often attends these tests. In the meantime, subtitle launchers copy their file to their laptop, switch on their projector and test the subtitles.

Characteristics of the venue such as distance between screen and projector, location (indoors or outdoors) and existence of booths will determine the size of the subtitles font, the luminosity of the projector, the location of the subtitles (on the screen where the film will be projected or on an independent screen), the positioning of the subtitles (at the top or at the bottom of the screen), and the location of the subtitle launcher. This technician may sit in the last or the first row of the ground floor, in the stage box or in a booth. The more isolated the subtitle launcher' seat is, the better he or she will work. When sitting at the ground floor, subtitle launcher may indeed struggle to hear the audio above loud chatters or may have to reply to questions and comments from the viewers, who sometimes are stricken by the presence of the subtitle launcher in the cinema.

Even though last-hour changes are not very frequent, they are not rare either. As mentioned above, the final cut of some films may be decided shortly before the festival and the screening copy may not arrive on time to the subtitling company. Therefore, subtitle launchers may 
have to deal with modifications of the film such as changes of order or elimination and addition of scenes.

222 If the festival warns the subtitling company that the screening copy is not identical to the copy that has been used to prepare the translation, a subtitle may be projected at the beginning of the screening warning the audience about the possible divergences between the film and the subtitles.

Finally, the sentimental implication and emotions caused by the cinema experience needs to be mentioned. Subtitle launchers work in an auditorium and they may be affected by the film as a conventional viewer. Even though subtitle launchers have already watched the movie, "the immersive space of the darkened movie theater" (Czach, 20I0: I4I), the big screen and imposing sound systems may awaken emotions while working. Laughter caused by comedies, frights at horror films and even tears while watching tragedies may affect the performance of those working at the venue such as subtitle launchers or interpreters. Elias (2008), a professional interpreter, comments on her experience:

my relation with films is rather neutral. It usually takes me months to realize if I like a film or not [...]. Just recently I started crying at the booth while interpreting Cherry Blossoms by Doris Dorrie. Luckily, I knew how long the film will be silent for so I managed to divert from it for three or four minutes and to recover my voice [my translation].

In general, working at film festivals involves working side by side with professionals from different sectors, which is enriching and exciting. Subtitle launchers have the opportunity to learn the more technical aspects of cinema from projectionists and video and audio techni- cians: the fragility of traditional film formats, the importance of contrast and brightness of the image or the relevance of high pitches in sound. Film festivals offer as well the chance to discover the artistic and aesthetic values of cinema from filmmakers and actors at interviews, presentations and press conferences as well as in face to face encounters during screening tests or even at lunch time. Sometimes translators may be able to ask directors what ambiguous scenes or dialogues actually mean, or even what their preferences on a controversial translation or subtitle are. It is often possible to learn about economic and business factors regarding cinema by listening to producers and production teams.

The various professionals involved in the cinema industry are focused on very different and specific aspects. Therefore subtitle launchers and AV translators may learn a lot about the texts they work with by experiencing film festivals, which offer an in-depth view of the complexity of audiovisual texts and the context in which they are conceived and developed.

\section{THE ROLE FILM FESTIVALS PLAY ON SOCIETY AND PERSPECTIVES FOR THE FUTURE}

Film festivals give access to films that rarely find their way into mainstream circuits and that open our small world to cultures and issues we barely know of. Di Giovanni (2008: 197-200) claims that film festivals together with subtitling offer the opportunity for the diffusion of otherwise ignored cinematic products and can go far in enhancing knowledge of extremely remote cultures and in leading events, communities and whole cultures form darkness to light.

These initiatives have a crucial role in society 
and in our understanding of the world. Gregory et al. (2005: 249) highlight that film festivals

represent a valuable opportunity to give visibility to a number of issues, but also to enhance a sense of community, to start discussion forums, to enable networking with press, general public and other filmmakers and, last but not least, to obtain media exposure, action and advocacy opportunities.

The revolution of digital video and laptop editing caused the reduction of film production costs, which enabled all kind of filmmakers to shoot films in spite of low budgets. Besides, an increase in the number of small film festivals held all over Spain and dealing with very specific topics such as surf ${ }^{6}$ was witnessed for several years. This promising scenario also meant an increase in subtitles demand due to the tight budgets of these films and the intrinsic characteristics of film festivals, which favour subtitling instead of dubbing, the most common AVT modality in Spain until recent years7.

Unfortunately, this fertile soil for culture, cinema and subtitling has been considerably damaged in the last few years. The economic crisis is affecting enormously the culture sector. In fact, according to Spanish newspapers such as El Pais the budget for culture has been cut by half in the last four years.

6 Di Giovanni (2008: 20I) observes the same tendency in Italy where "film festivals have been constantly increasing over the past few years, with a plethora of approaches and a variety of issues now being featured in the hundreds of festivals which are held throughout the country".

7 According to the Spanish Ministry of Culture (http://www.mcu.es/cine/docs/MC/BIC/20II/Distribucion/rr.Balance_Distr_Calif.pdf), in recent years there is a trend to show foreign films in Spain in a dubbed version as well as in a subtitled version. In 201 out of a total of 364 foreign films showed in Spain, I94 were both dubbed and subtitled, II2 were only dubbed and 58 were only subtitled.
While years ago the tendency seemed to be an increase in the amount of small film festivals, nowadays we face a much darker scenario (Piña, 20I2): drastic budget reductions in most of the festivals held all over Spain (for instance, Cines del Sur) and the complete disappearance of many others (Mostra del Mediterráneo, Mostra de Cinema Africà and Festival REC, to name but a few).

The beloved Punto de Vista Documentary Film Festival is a case in point. In September 20II its imminent suspension was made public. Directors, programmers, film critics and institutions united to show their unconditional support 8 "to the people who for over seven years have made of this festival a point of reference in national and international film scene". A petition was issued to the government of Navarra, the region where the film festival is held, to "urge the authorities to reflect on their responsibility towards the culture and the citizens for which they work". Finally it was decided that Punto de Vista will not be suspended. Unfortunately, the event will be held biennially instead of annually.

To conclude with a positive note we would like to add that in spite of the crisis -or maybe because of it- new and promising initiatives and ways of distribution have recently seen the light. This is the case of distribution platforms such as Distrify or online film festivals like Márgenes, Iber.film.america or Atlántida Film Fest, which seek either to offer a second life to high quality films which have barely been watched in Spain or to bring to our home screens films that have not been screened before in our country.

\footnotetext{
8 The letter of support is available at http://www. change.org/es/peticiones/apoyo-al-festival-de-cine-puntode-vista-de-pamplona-support-punto-de-vista-festival (last accessed 22 April 2013).
} 


\section{FINAL REMARKS}

This paper has shed light on electronic subtitling, a widely used AV modality in Spanish film festivals. This technique may vary depending on launching methods, diffusion methods and software systems. Electronic subtitles manually launched via projector present characteristics that differ from burnt in subtitles. As described in the paper, in this kind of subtitling shot changes are not taken into account for the segmentation of the translated text and timecodes are not needed because technicians launch the subtitles during the screenings. It is advisable for translators to be aware of these peculiarities in order to deliver a translation that matches the requirements of the modality. AV translators' know-how may also be enriched by experiencing film festivals as subtitle launchers or even as spectators because this kind of events offers an in-depth view of the complexity of films.

Unfortunately AV translators face many challenges that are not only related with the complexity of their task, but with their working conditions -such as the quality of the source written text, the use of pivot titles, the deadlines or the wages-, and the economic context. Festival suspensions and budget reduction obviously affect subtitling companies, freelance translators and subtitle launchers not only with regard to the workload, but also to the rates they may charge. In such conditions a presupposition that should be confirmed by research is that the quality of the preceding years is hard to achieve. Another research that could be very interesting is to test if spectators appreciate the different precision achieved by electronic subtitling and burnt in subtitling.

RECIBIDO EN JULIO DE 2013 ACEPTADO EN DICIEMBRE DE 2013 VERSIÓN FINAL DE ENERO DE 2014

\section{REFERENCES}

Bartoll, E. (2008). Paràmetres per a una taxonomia de la subtitulació. Doctoral dissertation, Barcelona: Universitat Pompeu Fabra

- (20I2a). "La sobretitulació d'obres teatrals". Quaderns. Revista de traducció, 19, 23-30

- (20I2b). La subtitulació: aspectes teòrics i practices, Vic: Eumo

Chaume, F. (2004). Cine y traducción, Madrid: Cátedra Czach, L. (2010). "Cinephilia, Stars, and Film Festivals". Cinema Journal, 49, Number 2, Winter, I39-I 45

Di Giovanni, E. (2007). "Films, Subtitles and Subversions". Linguistica Antverpiensia, New Series (LANS) 6. "A Tool for Social Integration? Audiovisual Translation from Different Angles, 51-66

- (2008). "From darkness to light in subtitling". Between Text and Image. Updating Research in Screen Translation. Amsterdam: John Benjamins, 197-2IO

Díaz-Cintas, J. \& A. Remael. (2007). Audiovisual translation: Subtitling, St Jerome Publishing

Díaz-Cintas, J. (200I). "Striving for quality in Subtitling: the role of a good dialogue list". (Multi) Media Translation: Concepts, Practices, and Research, Y. Gambier \& H. Gottlieb (eds.), Amsterdam: John Benjamins Publishing Company, I99-2II

Elias, C. (2008). "Als Dolmetscherin beim Film: Parlez-vous cinema?”. $M D U ̈$ (Mitteilungsblatt für Dolmetscher und Übersetzer) 55:3, 9-12

Gottlieb, H. (1997). Subtitles, Translation and Idioms. Doctoral dissertation, Copenhagen: University of Copenhagen

Gregory, S., G. Caldwell, R. Avni and T. Harding (2005). Video for change: a guide for advocacy and activism, London: Pluto Press

Ivarsson, I. (2004). "A short technical history of subtitles in Europe". [Online]. <http://www.transedit.se/history.htm> [Last accessed 23 June 20I3]

Ivarsson, I. \& M. Carroll. (1998). "The Code of Good Subtitling Practice". [Online]. <http://www. esist.org/ESIST\%2oSubtitling\%2ocode_files/ Code\%2oof\%2oGood\%2oSubtitling\%2oPractice_en.pdf> [Last accessed io December 2013]

Jüngst, H. E (20II). "Filmdolmetschen. Der Filmdolmetscher und seine Rollen". Trans-kom Journal of Translation and Technical Communication Research 4: 2, I76-19o 
Lecuona, L. (I994). "Entre el doblaje y la subtitulación: la interpretación simultánea en el cine”. Trasvases culturales: literatura, cine, traducción. Vitoria: Universidad del País Vasco-Euskal Herriko Unibertsitatea, 279-286

Ministerio de Cultura, Educación y Deporte. Boletin Informativo de Cine. Producción, exhibición y distribución de películas. 20II. [online] <http://www. mcu.es/cine/docs/MC/BIC/20II/Distribucion/II. Balance_Distr_Calif.pdf> [Last accessed 30 December 20I3]

Nornes, A. M. (2007). Cinema Babel: Translating Global Cinema, Minneapolis: University of Minnesota Press

Oncins, E., O. Lopes, P. Orero, J. Serrano and J. Carrabina (2012). "Multi language and multi system mobile application to make accessible live performing arts: All Together Now". JosTrans (Issue 20): Image, Music, Text...? Translating Multimodalities

Oncins, E. (2013a). "The Process of Subtitling at Film Festivals: Death in Venice?”. International Journal of Humanities and Social Science. Vol. 3 No. I4, 70-8o. [Online]. <http://www.ijhssnet.com/journals/Vol_3_No_I4_Special_Issue_July_2013/9. pdf $>$ [Last accessed ro December 20I3]

- (2013b). "The tyranny of the tool: Surtitling live performances". Perspectives: Studies in Translatology. (Manuscript provided by the author)

Piña, B. (20I2). "Crisis en los certámenes españoles. Festivales recortados". Caiman Cuadernos de Cine $53,53-55$
Raynor, W. (I986). "New Subtitle System May Translate Into Cinema Success". Miami Nerws: 30. [Online]. <http://news.google.com/newspap ers? $n i d=2206 \&$ dat $=198603$ I9 $\&$ id $=D_{3}$ NYAAAAIB A J\&sjid=QjoNAAAAIBAJ\&pg=2657,5571693> [Last accessed 22 April 2013]

Russo, M. (1997). "Film interpreting: Challenges and constraints of a semiotic practice". Conference Interpreting: Current Trends in Research. John Benjamins: Amsterdam, I88-I92

- (2000). "L'interpretazione simultanea dei film e la didattica: l'esperienza di un festival". Interpretar traducir textos de la(s) cultura(s) hispanica(s). Bologna: CluEB (Cooperativa Literaria Universitaria Editrice Bologna), 267-285

- (2003). "L'interpretazione simultanea dei film: dalla preparazione all'improvisazione”. Le questioni del tradurre: comunicazione, comprensione, adeguatezza traduttiva e ruolo del genere testuale. Edizioni Associate Editrice Internazionale: Roma, 57-68

- (2005). "Simultaneous film interpreting and users' feedback", Interpreting International Journal of Research and Practice in Interpreting 7: I, I-26

Vermeulen, A. (20II). "The Impact of Pivot Translation in AVT", International Journal of Translation, Special number on Screens we live by: an updated insight into audiovisual translation research, $\mathrm{R}$. Agost (ed.), Bahri Publications, vol.23, n², II9-I34

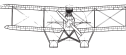

225 